\title{
POWER QUALITIES OF THE HIGHER EDUCATION INSTITUTION STUDENTS: KETTLEBELL LIFTING
}

\author{
Griban G. P., Tkachenko P. P.
}

\section{INTRODUCTION}

The current situation in the system of physical education at higher education institutions in Ukraine has brought to the fore the contradictions between the intellectualization and humanization of the educational level of a future specialist, who should master not only compulsory and optional components of the educational program but also one of the basic cultures the physical culture of the individual. A great range of tools, methods, and forms of physical development is not sufficient to form the physical culture of the individual, the most important components of which are worldview, values, motivation, width and depth of knowledge in physical culture, and most importantly - the activity aspect of the realization of physical culture and health-improving values.

The changes taking place at the present stage of the development of the physical education system are not only the formation of the physical culture, which requires the educational process to abandon authoritarian teaching methods, taking into account students' interests and needs in personal physical and spiritual improvement but also the formation of new identification stereotypes of various manifestations of motor activity. In addition, motor activity should correspond to their lifestyle, socio-psychological and morphofunctional statuses, the features of mentality, which are integrated into the physical culture and educational space of personalized pedagogical technologies and the ways of their implementation.

Kettlebell lifting is one of the means of physical education, health improvement, preparation for future professional activity. Due to the wide variety of exercises in this kind of sport, as well as the great educational, health-improving, and applied value, kettlebell lifting is included in the programs of sports competitions at the city, regional, national, European, and world levels. On the one hand, it is an available means of comprehensive physical development and an aid to the development of physical qualities in other sports, on the other hand - it is 
a means of power sports proliferation and a healthy lifestyle promotion among young people ${ }^{1}$.

Based on the requirements of legal documents imposed on the training of future professionals, the system of physical education at higher education institutions should be aimed at improving health, physical fitness, efficiency, and the formation of physical fitness competences of the students. At the same time, regular kettlebell lifting training is one of the available means of the students' physical education, health improvement, physical qualities development, preparation for future professional activities, etc.

\section{Person-centered choice of motor activity by students in the physical education process}

The liberalization of socio-cultural processes in society determines the desire of young people to deny the established physical culture and sports traditions at higher education institutions and the formation of new identification stereotypes of various manifestations of physical activity, corresponding optimally to their lifestyle, socio-psychological, and morphofunctional statuses, the features of mentality, and requires integration of personalized pedagogical technologies and methods of their implementation into the physical culture and educational space.

The wearing out of physical education paradigms and socio-cultural limitations of traditional methodological constructions of the educational process implementation, caused by excessive didactics and authoritarian style of management, led to humanitarian orientation and democratic nature of evolutionary transformations in the physical education of the students of higher education institutions. In our opinion, one of the important reasons for the low efficiency of physical culture and healthimproving processes is the imperfection of the system of implementation of various areas of physical activity, namely: physical education, sports, recreation, rehabilitation, and vocational training, which do not meet the requirements of socio-economic conditions of the life activity of modern students of higher education institutions.

The formation and realization of the desire to use physical activity in everyday life should be based on the individual characteristics and needs of each student. At the same time, it is important to form the students' belief in the need for regular use of various forms of physical education

1 Пічугін М.Ф., Грибан Г.П., Романчук В.М. та ін. Гирьовий спорт: навч.-метод. посіб. / За ред. Г.П. Грибана. Житомир : ЖВІНАУ, 2011. 880 с. 
and sports. The vast majority of students have no desire to engage in physical education and sports (Table 1). Unfortunately, $42.6 \%$ of students consider the main purpose of attending physical education classes to be getting credit but not improving the appearance (physique, shape of the muscular corset) and sports results, or getting positive emotions in physical education classes. An important reason is the lack of a differentiated approach to students during physical activity and while choosing the physical activity in the educational process. Therefore, the traditional system of physical education at higher education institutions does not fully solve the problem of optimizing physical fitness, physical condition, and the motivation sphere formation of students ${ }^{2}$.

Table 1

The male students' purpose of attending classes in physical education $(\%, n=501)$

\begin{tabular}{|c|c|c|c|}
\hline \multirow{2}{*}{ Purpose } & \multicolumn{2}{|c|}{ The year of study } & General \\
\cline { 2 - 3 } & I & II & \\
\hline Improving physical performance & 63.6 & 50.0 & 56.9 \\
\hline Getting a credit & 47.5 & 37.8 & 42.6 \\
\hline $\begin{array}{c}\text { Improving appearance (physique, shape of } \\
\text { the muscular corset) }\end{array}$ & 33.3 & 24.5 & 28.4 \\
\hline Improving sports results & 26.3 & 22.5 & 24.4 \\
\hline Getting positive emotions & 20.2 & 20.4 & 20.3 \\
\hline
\end{tabular}

The key positions in updating the pedagogical system of physical education should be the democratization and humanization of its basic provisions, the development of socio-cultural aspects, strengthening educational orientation, and creative acquirement of the physical culture values $^{3}$. The implementation of these areas should be based on the elimination of contradictions that give rise to a distorted attitude of young people to the values of physical culture. For this purpose it is necessary to overcome pedagogical conservatism in the system of physical education, to revive its democratic traditions and ideals; to eliminate the growing alienation of the system of physical education from public life, the development of personality and culture, to build new

2 Глазирін І.Д. Основи диференційованого фізичного виховання. Черкаси : Відлуння-Плюс. 2003. 352 с.

3 Сериков В.В. Личностно ориентированное образование. Педагогика. 1994. № 5. C. 17. 
relationships between a teacher and a student on the basis of commonwealth and trust; to free the system of physical education from total unification and standardization, to use various forms of modern physical culture and health-improving technologies ${ }^{4}$.

Overcoming the unitarity of physical culture and health-improving technologies used in pedagogical practice (in the traditional system of physical education) and their evolutionary replacement by the technologies of the humanistic orientation of person-centered content contribute to the optimal satisfaction of socio-psychological and biological needs of students in physical activity, which is one of the priority areas of the modernization of physical education system at higher education institutions. The basis of person-centered physical education is the ability to influence the ethical and aesthetic spheres of personality, resulting in the ability to see, perceive, and understand the beautiful points in sports movements, to imitate them in their actions and activities through their own physical improvement.

Person-centered functions should be considered in two aspects. The first aspect involves forming the differentiation of certain values by students concerning the degree of their importance personally for themselves. The second involves the formation of moral, ideological, ethical, and aesthetic assessment of the phenomena of reality by students and finding themselves in these phenomena. As a result, the socialization of the individual is based on the assimilation of the values of social experience, the formation of an active life position. Through the implementation of physical culture and health-improving activities, knowledge about the possibilities of one's own organism is expanded, which forms the basis of the search for ways of self-improvement ${ }^{5}$.

With all the variety of modern theoretical educational, methodical, and conceptual approaches to the process of physical education as the main system-forming link, a set of personal physical and sociopsychological characteristics of students is distinguished. In turn, this creates the need to form conditions for a person-centered physical culture and health-improving system of pedagogical actions, the implementation

\footnotetext{
${ }^{4}$ Грибан Г.П. Життєдіяльність та рухова активність студентів : монографія. Житомир : Вид-во «Рута». 2009. 593 с.

5 Лубышева Л.И. Современный ценностный потенциал физической культуры и спорта и пути его освоения обществом и личностью. Теория и практика физической культуры. 1997. № 6. С. 10-15. 
of methodical differentiation in accordance with the laws of physical, mental, and social development of each student.

Currently, the departments of physical education at higher education institutions are facing the need to enrich the pedagogical content of the discipline of Physical Education, to radically change its syllabus, to increase the number of programs, educational and person-centered orientation on health, leisure, etc. Despite the intensive introduction of innovative physical education programs and pedagogical technologies in the processes of teaching and education, technological innovations of person-centered content in the system of physical education have not yet become widespread. Therefore, the theoretical and methodical substantiation of the need to modernize the system of physical education at educational institutions and construct it on the principles of personcentered content today are important scientific and practical tasks of optimizing physical activity and maintaining physical education as a discipline at higher education institutions of Ukraine.

A person-centered approach involves considering this process from the standpoint of harmony and expediency. In this case, the educational process has an educational, developmental, and formative effect on the personality of a student, who masters a certain system of scientific knowledge, practical skills, and abilities, forms a worldview, develops physical abilities, etc. This approach to the process of physical education allows formulating a key concept of research - person-centered physical education, which should be understood as the process of purposeful development of the values of physical culture and sports, physical selfimprovement, and a healthy lifestyle, the development of motor skills, individual sports and health-improving lifestyle and social activity.

An attractive and important form of physical education functioning is sports activity. In classes, one of the students' favorite sports reveals psychophysical abilities, increases their efficiency, etc. Sports activity creates a basis for the comprehensive development of physical qualities and motor skills, that is it forms the preconditions for their development. The need for sports is determined by the needs of society - to educate highly qualified physically trained professionals ${ }^{6}$. Our research suggests that the majority of students are involved in sports not to achieve high

${ }^{6}$ Бойко Д.В., Романчук В.М., Пронтенко К.В. Ефективність програми проведення спортивно-орієнтованої форми фізичного виховання студентів 3 використанням засобів гирьового спорту. Вісник Кам'янеиь-Подільського наи. універ. Фізичне виховання, спорт і здоров'я людини. 2012. Вип. 5. С. 210-219. 
sports results, participate or win in competitions but to meet their personal needs. The priority means of physical culture and sports that students want to engage in are skiing, gym machine exercises, hiking, shaping, swimming, skiing, martial arts, wrestling, powerlifting, kettlebell lifting, bodybuilding, tennis, ice-skating, and other types of physical activity (Table 2).

Table 2

The most popular types of physical culture and sports among male students of the 1st-2nd years of study at higher education institutions

\begin{tabular}{|c|c|c|c|}
\hline $\begin{array}{c}\text { Types of physical culture } \\
\text { and sports }\end{array}$ & $\begin{array}{c}\text { Train } \\
\text { systematically }\end{array}$ & $\begin{array}{c}\text { Train } \\
\text { periodically }\end{array}$ & $\begin{array}{c}\text { Want to } \\
\text { train }\end{array}$ \\
\hline Skiing & 6,1 & 19,8 & 40,1 \\
\hline Martial arts & 5,6 & 13,7 & 37,1 \\
\hline Wrestling & 7,1 & 17,8 & 35,5 \\
\hline Powerlifting & 6,1 & 9,1 & 35,1 \\
\hline Kettlebell lifting & $\mathbf{8 , 1}$ & $\mathbf{1 8 , 8}$ & $\mathbf{3 1 , 0}$ \\
\hline Hiking & 13,7 & 21,3 & 30,5 \\
\hline $\begin{array}{c}\text { Athletic gymnastics, } \\
\text { bodybuilding }\end{array}$ & 9,1 & 17,8 & 29,4 \\
\hline Swimming & 13,2 & 27,9 & 29,4 \\
\hline Tennis & 16,8 & 27,9 & 28,9 \\
\hline Ice-skating & 7,1 & 19,3 & 28,4 \\
\hline Rhythmic gymnastics & 3,6 & 12,2 & 27,9 \\
\hline Badminton & 6,6 & 17,8 & 27,9 \\
\hline Volleyball & 7,6 & 33,5 & 22,3 \\
\hline Cycling & 19,3 & 38,6 & 21,8 \\
\hline Recreational running & 23,9 & 35,5 & 21,8 \\
\hline and walking & 12,2 & 24,4 & 20,8 \\
\hline Basketball & 19,8 & 27,4 & 20,3 \\
\hline Gym machine exercises & 28,9 & 37,6 & 15,7 \\
\hline Football & 43,7 & 23,9 & 13,7 \\
\hline Walking & & &
\end{tabular}

The feature of the formation technologies of students' personcentered choice of the motor activity types is personal motivation and awareness of the chosen type of physical culture, health-improving, and sports activities, where the principle of democratization and humanization in joint activities of a teacher and a student can be implemented to the fullest extent. The students' interest in the process of physical education, organized according to a person-centered form of 
training, is stimulated by the independent choice of a particular sports specialization. This gives students the opportunity to improve themselves in the chosen sport, and participation in competitions motivates and increases students' interest in the training process ${ }^{7}$.

It should be noted that the values of the selected types of physical activity differ favorably from the values of the traditional approach in the use of physical exercises for the physical development of students. Their implementation contributes to the development of original forms of motor activity with the priority of educational, fitness, and healthimproving functions of physical culture ${ }^{8}$.

Thus, the modern system of physical education needs to change the methodological and methodical approaches to physical culture and health-improving activities of students. A promising direction for solving these problems is the introduction of a person-centered form of physical education organization at higher education institutions, taking into account the free choice of sports. What should be taken into account is the facilities and resources, motivation and preferences of students, the specialists in sports among the teaching staff of the Department of Physical Education. One of the sports that helps to solve this problem is kettlebell lifting, which is very popular among students and has a number of advantages, namely: economic feasibility, easy competitive exercises, accessibility in training, a wide health-improving and training orientation, etc ${ }^{9}$.

At the same time, the investigation of the students' interest in exercises with kettlebells during the physical education process found that $38.3 \%$ of students were interested in this type of sport, $19.3 \%$ could not decide, and $42.4 \%$ did not like kettlebell lifting. At the same time, there is a high level of direct relationship between the quality of the motives structure indicators of students and a teacher who conducts classes in these groups. An experienced teacher has much better

7 Попрошаев А.В., Мунтян А.В. Преимущества секционной формы организации учебного процесса по дисциплине «Физическое воспитание». Физическое воспитание студентов. 2011. № 4. С. 67-71.

8 Бойко Д.В., Романчук В.М., Пронтенко К.В. Ефективність програми проведення спортивно-орієнтованої форми фізичного виховання студентів 3 використанням засобів гирьового спорту. Вісник Кам'янещь-Подільського наи. універ. Фізичне виховання, спорт і здоров'я людини. 2012. Вип. 5. С. 210-219.

Акишин Б.А. Опыт организации спортивно-ориентированного физического воспитания в вузе. Культура физическая и здоровье. 2008. № 4. C. $17-18$. 
indicators: the higher the learning motivation is, the higher the success in physical education is. Thus, the indicators of a teacher, who is indifferent to the problems of students' motivation, are mostly opposite and the ratio of positive attitude of students to physical education is determined by shortcomings in the content, forms, methods, and organization of the educational process ${ }^{10}$.

The generalization of experience, literature sources, and our own research made it possible to identify a number of existing controversial issues:

- between the objective need of modern society in the education of harmoniously developed specialists with a high level of physical health, physical fitness, working capability and insufficient development of this problem in scientific, theoretical, and methodical aspects;

- between the social significance of obtaining theoretical knowledge, practical skills and the level of physical fitness and the constant reduction of the number of hours for the study of the Physical Education discipline;

- between the need to use new fitness and health-improving technologies, namely, power exercises with kettlebells, in combination with traditional technologies and the lack of training methods and material support of the educational process;

- between the need for purposeful formation of the motivational and values-based attitude of students to exercises with kettlebells during the physical education process and the lack of appropriate technologies.

Therefore, the modernization of the physical education system of students on the basis of person-centered choice of motor activity exercises with kettlebells, ensures their involvement in regular physical exercises, forms their needs for physical development, improves mental performance and learning activity. Kettlebell lifting helps improve students' health, increase their level of physical fitness, develop positive motivation and a stable need for physical activity and sports.

\section{Using exercises with kettlebells for the development of power qualities of students}

Kettlebell lifting promotes the development of power, general and power endurance, flexibility, coordination of movements, physical

10 Свіргунець В. Формування інтересів і мотивів до занять 3 фізичного виховання. Вісник Технологічного університету Поділля. № 5. Ч. 3 (48). Хмельницький, 2002. С. 43-47. 
performance improvement, the formation of moral, volitional, and mental qualities of higher education institution students. Power readiness achieved by students in the process of specialized training promotes high results in professional activities, life, and physical activity. At the same time, the variety of labor activities in various spheres of human life requires from specialists a high level of power qualities development ${ }^{11}$.

Regular exercises with kettlebells gradually increase the volume of the heart muscle, expand the network of blood vessels; change blood composition (increase the number of erythrocytes, hemoglobin); increase chest volume, the vital capacity of the lungs; improve the activity of the central nervous system, mental performance; increase the intensity and concentration of attention.

Despite a significant amount of psychological and pedagogical research, the problem of developing power qualities of higher education institution students by means of kettlebell lifting in education remains relevant due to a number of advantages of using kettlebells in physical education process. Among them are accessibility, simplicity, healthimproving orientation, and economic efficiency. The exercises with kettlebells are easy and fast to learn, a wide range of exercises allows conducting classes with many students, improving students' health, fitness, functional status, and efficiency, developing power qualities and all muscle groups, solving tasks of the formation and correction of body structure.

At the same time, exercises provide favorable conditions for the optimal functioning of the whole body, not just the muscular system. Selecting special exercises, dosing them, depending on the physical condition, one can purposefully affect the body, change its certain functions, and restore damaged systems. Gradually increase in the amount of physical activity provides general fitness, which is the basis for the overall physical condition and performance improvement. Regular exercises lead to the restructuring of organs and systems due to the elimination of physiological disorders and the normalization of pathologically altered functions 12 .

The development of power during physical training is accompanied by the improvement of all organs and systems of students, improving their performance. The positive changes lead to further development of the organism, opening its reserve possibilities, to the improvement of blood

11 Воропаев В.И. Гиревой спорт в учебном процессе по физическому воспитанию. Тезисы обл. науч.-практ. конф. Воронеж : ВАУ, 1988. С. 47-48.

12 Присяжнюк С.І. Фізичне виховання. Київ : ЦУЛ. 2008. 502 с. 
circulation, activation of endocrine glands which produce hormones for the work of muscles. Such training increases muscles in volume due to the thickening of muscle fibers and improves their efficiency.

Power training includes various exercises with kettlebells, which make it possible to affect either a large part of the muscular system or individual muscle groups selectively. Like physical training in general, power training has two directions: general power training and special power training. General power training is aimed at the harmonious development of all major muscle groups that are important for the physical development and fitness of a student, and special power training in kettlebell lifting involves the development of power qualities in kettlebell lifting, linking the power of the respective muscle groups with the technique of lifting kettlebells and performing various competitive and supporting exercises ${ }^{13}$. Thus, the means of special power training are exercises with kettlebells, which are similar to competitive by the nature of the muscular effort and the structure of movements, and actually competitive exercises.

Hypokinesia decreases the power of healthy young people by $26 \%$, lessens the duration of the activity, causes changes in power characteristics and certain muscles. The power of the upper extremities is changed less than the power of the leg muscles ${ }^{14}$. This should be taken into account when designing a professional physical education program for future specialists in various fields (along with the predominant development of the muscles of the back, neck, and arms, strengthening the muscles of the legs is important). At the same time, exercises with kettlebells can effectively influence the expansion of the range of functional capabilities, increasing the range of motor activity, ensuring the body's adaptation to the many factors of activities, including the development of necessary professionally important motor skills.

A large number of exercises with kettlebells are performed while bending the body forward and straightening it back. Such bending with different amplitudes can be performed from 200 to 500 times in a class, which significantly strengthens the muscles of the back, shoulder girdle, legs, abdominal muscles - forming a core, which is important for many

${ }^{13}$ Грибан Г.П. Життєдіяльність та рухова активність студентів : монографія. Житомир : Вид-во «Рута». 2009. 593 с.

${ }^{14}$ Какурин А.И., Катковский В.С., Козлов А.Н. Влияние гипокинезии на некоторые показатели работоспособности и функцию дыхания человека. Москва : Наука. 1963. С. 226-229. 
professional activities of future professionals ${ }^{15}$. The power gained by athletes in the process of natural muscle development and in physical education classes at higher education institutions is insufficient to ensure their diverse development, to achieve high sports results, and readiness for professional activities ${ }^{16}$. During both physical and mental work, kettlebell lifters get tired much later than their peers. Systematic exercises with kettlebells increase self-confidence, develop such moral and volitional qualities as courage, determination, purposefulness, persistence, endurance, will to win, a sense of collective responsibility, mutual assistance ${ }^{17}$.

Power exercises are also the most effective to strengthen bones and build muscles. They are performed with a load of 70 to $100 \%$ of the maximum, with a small number of repetitions, low pace, and a long rest between sets. Power training provides a fairly large load for the students with a high level of physical fitness in a relatively short period of time ${ }^{18}$.

At the age of 17-18 years, the muscular system reaches its maximum values, the comprehensive improvement of motor function is completed, and the topography ratio of the power of different muscle groups, which is characteristic of adults, is aligned. The increase in the maximum power indicators and speed of movements indicates that the developing musculoskeletal system becomes active in various functional parameters. Body weight reflects the features of developmental processes. It is hereditarily determined, but fairly mobile, it responds quickly to changes in the biosocial environment and characterizes maturity.

In addition, research confirms that kettlebell lifting forms the stable motivation for physical education and sports, physical self-improvement, a healthy lifestyle, personal experience of applying physical education in life ${ }^{19}$. Regular kettlebell lifting training has been shown to maintain high performance, the effective development of power, general and power

15 Воротынцев А.И. Гири. Спорт сильных и здоровых. Москва : Сов. спорт, 2002. 272 c.

${ }^{16}$ Грибан Г.П. Життєдіяльність та рухова активність студентів : монографія. Житомир : Вид-во «Рута». 2009. 593 с.

${ }^{17}$ Грибан Г.П., Пронтенко К.В., Пронтенко В.В. та ін. Гирьовий спорт у вищих навч. закладах : навч. посіб. / За ред. Г.П. Грибана. Житомир : Вид-во «Рута». 2014. 400 c.

18 Міхеєнко О.І. Валеологія: основи індивідуального здоров'я людини : навч. посіб. для студентів вузів. Суми : Університетська книга. 2010. 448 с.

${ }^{19}$ Грибан Г.П. Життєдіяльність та рухова активність студентів : монографія. Житомир : Вид-во «Рута». 2009. 593 с. 
endurance, static endurance of the torso muscles, coordination skills, having a positive effect on the cardio-respiratory system and emotional state of students ${ }^{20}$. It has been found that bradycardia of qualified kettlebell lifters (when heart rate at rest is $55-56$ beats per $1 \mathrm{~min}$ ) indicates the development of endurance in the process of training with kettlebells. The use of kettlebell lifting in the educational process helps to eliminate various defects of body structure, forms the correct posture, improves the functional state of the musculoskeletal and cardiorespiratory systems, develops confidence, optimism, promotes a good $\operatorname{mood}^{21}$.

Kettlebell lifting promotes the development of power, general and power endurance, flexibility, coordination of movements, the improvement of physical performance, the formation of moral, volitional, and psychological qualities of higher education institution students $^{22}$. Power exercises also have a positive effect on health, performance, physical and psychological qualities. The optimal level of power development is an effective factor in preventing diseases and ensuring locomotor and energy-producing functions of the body.

The research of V.Y. Andreichuk ${ }^{23}$ and other scientists indicate that systematic exercises with kettlebells increase self-confidence, develop such moral and volitional qualities as courage, determination, perseverance, purposefulness, endurance, will to win, a sense of collective responsibility. In the process of training with kettlebells, stable motivation of students for physical education and sports, physical selfimprovement, a healthy lifestyle, personal experience of applying physical education in life is formed. The exercises with kettlebells make it possible to conduct classes with many students, improve their health, fitness, functional status, and performance, develop all muscle groups,

20 Пічугін М.Ф., Грибан Г.П., Романчук В.М. та ін. Гирьовий спорт : навч.-метод. посіб. / За ред. Г.П. Грибана. Житомир : ЖВІНАУ, 2011. 880 с.

${ }^{21}$ Фролов А.Ф., Литвинов В.А. Гиревой спорт и здоровье. Гиревой спорт в России. Пути развития и современные технологии в подготовке спортсменов высокого класса : 1-я Всерос. науч.-практ. конф. Ростов н/Д.: РГСУ, 2003. C. 96-99.

22 Магльований А.В., Шимечко I.M., Боярчук О.М. Динаміка показників фізичного здоров'я студентів, які займаються силовими вправами. Педагогіка, психологія та медико-біологічні проблеми фізичного виховання та спорту : зб. наук. пр. / за ред. С.С. Срмакова. Харків : ХДАДМ (ХХПІ). 2011. № 1. С. 80-83.

23 Андрейчук В.Я. Методичні основи гирьового спорту : навч. посібник. Львів : Тріада плюс, 2007. 500 с. 
effectively solve the problem of forming and correcting certain parts of the body, form willpower, and improve athletic performance. In the physical education process, exercises with kettlebells can be performed both in the gym and outdoors, alone and in groups.

A conscious attitude of students to kettlebell lifting allows solving the problems of physical development and physical fitness effectively. At the same time, students must be taught to clearly set goals and objectives of training with kettlebells, to gain the necessary knowledge and to understand their applied value, to realize the health-promoting importance of physical exercises with kettlebells, to master skills and abilities, etc. A responsible attitude to kettlebell lifting will contribute to an in-depth mastery of the theory and methods of physical culture and health-improving activities in later life. At the same time, our research has shown that the activation of the educational process of physical education is based on practical experience, theoretical, conceptual, and operational components of achieving the objectives, taking into account personal factors of the educational process. The personal position of the subjects (student - teacher) of educational and extracurricular physical culture and health-improving activities is the factor that allows solving the problems of involving young people in active exercises and maintaining a healthy lifestyle.

Therefore, the content of physical education classes with a personcentered choice of motor activity, which is kettlebell lifting, should include a positive emotional attitude to training with kettlebells, a system of knowledge, interests, motives, and beliefs, aimed at mastering values of kettlebell lifting; the students' awareness of the value of systematic exercises with kettlebells; the need for a healthy lifestyle and the encouraging others to follow it; focus on creating conditions for further personal physical development, maintaining high efficiency and helping others to meet these needs in future professional activities; selfimprovement in kettlebell lifting in the process of further life. Thus, it is necessary to provide a student with a whole range of motives and interests in the means of motor activity, to develop the need for it, to create favorable conditions. In this case, the purpose of exercises with kettlebells is the initial component that determines the functioning of the pedagogical process.

Person-centered orientation of students to kettlebell lifting as a motor activity cannot be determined solely on the basis of their needs and interests. The same needs and interests, which have acquired the status of motives for activity, can be realized by the individual in order to achieve 
different values. It is very important to know and take into account the values of students, to determine their main motives and their rating significance in the general hierarchy that motivate applicants to do exercises with kettlebells. Among the dominant motives, the following ones have been found: getting positive emotions in classes, improving health, modern sports facilities of a university, the possibility to choose a kind of sport, health orientation, etc. (Table 3). The studies also show that there is a difference in the motives significance between the firstand second-year students. Thus, health improvement takes first place for the first-year students and only fourth place for the second-year students, the possibility to choose a sport - seventh place for freshmen, and first place for the second-year students.

Table 3

The motives encouraging students to do exercises with kettlebells (rating place, $\mathbf{n}=501$ )

\begin{tabular}{|c|c|c|c|}
\hline \multirow{2}{*}{ Motives } & \multicolumn{2}{|c|}{$\begin{array}{c}\text { The year } \\
\text { of study }\end{array}$} & \multirow{2}{*}{$\begin{array}{c}\text { Rating } \\
\text { place }\end{array}$} \\
\cline { 2 - 3 } & I & II & \\
\hline Enjoying classes & 2 & 2 & 1 \\
\hline Health improvement & 1 & 4 & 2 \\
\hline Modern sports facilities of a university & 4 & 3 & 3 \\
\hline The possibility to choose a kind of sport & 7 & 1 & 4 \\
\hline Wellness orientation of classes & 5 & 5 & 5 \\
\hline Physical qualities development & 3 & 9 & 6 \\
\hline Desire to lose weight & 9 & 6 & 7 \\
\hline Desire to acquire new knowledge, skills, and abilities & 8 & 7 & 8 \\
\hline Improving body structure & 6 & 11 & 9 \\
\hline Self-affirmation & 10 & 8 & 10 \\
\hline Rest from mental work & $11-12$ & 10 & 11 \\
\hline Achieving new sports results & $11-12$ & 12 & 12 \\
\hline
\end{tabular}

It should be noted that the motivational and values-based attitude of students to exercises with kettlebells is a set of factors that encourage physical culture and health-improving activities based on internal needs, external motives, that are socially formed and acquire personal significance, and values.

\section{CONCLUSIONS}

1. The analysis of scientific and methodical literature allowed establishing that the improvement of the physical education system of 
higher education institutions on the basis of person-centered choice of physical activity helps to increase the interest of students in the educational process, improves health, physical fitness, provides them with regular physical exercises and sports, forms the need for physical development, promotes an increase in mental working capacity and the indicators of educational activity. It was designated that the personcentered form of physical activity in physical education classes, namely the use of kettlebell lifting, significantly improves the quality of the physical education process at higher education institutions and has a number of advantages over traditional means of physical culture.

2. Physical education on the basis of the person-centered choice of kettlebell lifting as the main motor activity of a student is of great importance for the training of highly educated and physically advanced professionals. The exercises with kettlebells are one of the effective means of developing not only power qualities and motor skills but also the ability to adapt to the difficult conditions of future professional activity. The use of kettlebell lifting during the physical education process significantly improves the functional state, health, physical fitness and development, and working efficiency of students, forms a positive motivation for regular exercises and sports.

3. It was found that the dominant motives of students to the choice of kettlebell lifting as the main type of physical activity are getting positive emotions during kettlebell lifting training, improving health, modern sports facilities of a university, the possibility to choose a kind of sport, health orientation, etc. There is a difference in the motives significance between the first- and second-year students, which can be changed significantly while studying at a higher education institution. The formation of a motivational and values-based attitude to the means of kettlebell lifting occurs only in the case of directing a student to the possibility of realizing one's most significant needs in this activity.

\section{SUMMARY}

The analysis of the improvement of the physical education system at higher education institutions on the basis of the person-centered choice of motor activity is presented, the formation of new identification stereotypes of various displays according to lifestyle, sociopsychological and functional statuses, features of mentality, and integration of personalized pedagogical technologies and methods of their implementation in the physical culture and educational space is revealed. A set of questions related to the study of person-centered 
choice of sports by athletes to increase motor activity is generalized and scientifically substantiated. It is established that the physical education process should be dominated by innovative physical culture and healthimproving technologies according to the personal choice of students. At the same time, the person-centered focus on kettlebell lifting as the main type of motor activity is not able to take into account all the needs and interests of students. The experience of the power qualities development regularities during kettlebell lifting training in the physical education process is generalized. It is defined that the dominant motives of students are getting positive emotions during kettlebell lifting training, improving health, modern sports facilities of a university, the possibility to choose a kind of sport, health orientation, etc.

\section{REFERENCES}

1. Акишин Б.А. Опыт организации спортивно-ориентированного физического воспитания в вузе. Культура физическая $и$ здоровье. 2008. № 4. С. 17-18.

2. Андрейчук В.Я. Методичні основи гирьового спорту : навч. посібник. Львів : Тріада плюс, 2007. 500 с.

3. Бойко Д.В., Романчук В.М., Пронтенко К.В. Ефективність програми проведення спортивно-орієнтованої форми фізичного виховання студентів 3 використанням засобів гирьового спорту. Вісник Кам'янець-Подільського наи. універ. Фізичне виховання, спорт і здоров'я людини. 2012. Вип. 5. С. 210-219.

4. Воропаев В.И. Гиревой спорт в учебном процессе по физическому воспитанию. Тезисы обл. науч.-практ. конф. Воронеж : ВАУ, 1988. С. 47-48, 57.

5. Воротынцев А.И. Гири. Спорт сильных и здоровых. Москва : Сов. спорт, 2002. $272 \mathrm{c}$.

6. Глазирін І.Д. Основи диференційованого фізичного виховання. Черкаси : Відлуння-Плюс. 2003. 352 с.

7. Грибан Г.П. Життедіяльність та рухова активність студентів : монографія. Житомир : Вид-во «Рута». 2009. 593 с.

8. Грибан Г.П., Пронтенко К.В., Пронтенко В.В. та ін. Гирьовий спорт у вищих навч. закладах : навч. посіб. / За ред. Г.П. Грибана. Житомир : Вид-во «Рута». 2014. 400 с.

9. Какурин А.И., Катковский В.С., Козлов А.Н. Влияние гипокинезии на некоторые показатели работоспособности и функцию дыхания человека. Москва : Наука, 1963. С. 226-229. 
10.Лубышева Л.И. Современный ценностный потенциал физической культуры и спорта и пути его освоения обществом и личностью. Теория и практика физической культуры. 1997. № 6. C. $10-15$.

11. Магльований А.В., Шимечко I.М., Боярчук О.М. Динаміка показників фізичного здоров'я студентів, які займаються силовими вправами. Педагогіка, психологія та медико-біологічні проблеми фізичного виховання та спорту : зб. наук. пр. / за ред. С.С. Єрмакова. Харків : ХДАДМ (ХХПІ). 2011. № 1. С. 80-83.

12. Міхеєнко О.І. Валеологія: основи індивідуального здоров'я людини : навч. посіб. для студентів вузів. Суми : Університетська книга. 2010. 448 с.

13.Пічугін М.Ф., Грибан Г.П., Романчук В.М. та ін. Гирьовий спорт : навч.-метод. посіб. / За ред. Г П. Грибана. Житомир : ЖВIНАУ, 2011. $880 \mathrm{c}$.

14.Попрошаев А.В., Мунтян А.В. Преимущества секционной формы организации учебного процесса по дисциплине «Физическое воспитание». Физическое воспитание студентов. 2011. № 4. C. 67-71.

15.Присяжнюк С.І. Фізичне виховання. Київ : ЦУЛ. 2008. 502 с.

16. Свіргунець В. Формування інтересів і мотивів до занять 3 фізичного виховання. Вісник Технологічного університету Поділля. 2002. № 5. Ч. 3 (48). С. 43-47.

17.Сериков В.В. Личностно ориентированное образование. Педагогика. 1994. № 5. С. 17.

18.Фролов А.Ф., Литвинов В.А. Гиревой спорт и здоровье. Гиревой спорт в России. Пути развития и современные технологии в подготовке спортсменов высокого класса : 1-я Всерос. науч.-практ. конф. Ростов н/Д.: РГСУ, 2003. С. 96-99.

19.Griban G., Smiianov V., Lyakhova N., Tkachenko P., Harlinska A., Dovgan N., Karpiuk R., Brytan Yu. (2021). The impact of nutritional quality on the students' health. Acta Balneologica, 1(163), 43-54. doi: 10.36740/ABAL202101107.
20. Griban G., Kuznietsova
O., Tkachenko
P., Oleniev D., Khurtenko O., Dikhtiarenko Z., Yeromenko E., Lytvynenko A., Khatko A., Pusto-liakova L. (2020). Formation of the students' volitional qualities in the process of physical education. International Journal of Human Movement and Sports Sciences, 8 (6), 505-517. doi: 10.13189/saj.2020 http//www.hrpub.org

21.Griban G., Kuznietsova O., Lyakhova N., Prystynskyi V., Oleniev D., Otravenko O., Pantus O. (2021). Dynamics of students' 
fitness level while differentiating physical education classes in accordance with their health and nosology of diseases. Wiadomości Lekarskie, 74 (3 p. II), 641-646. doi: 10.36740/WLek202103214.

22. Prontenko K., Griban G., Prontenko V., Andreychuk V., Tkachenko P., Kostyuk Yu., Zhukovskyi Ye. Kettlebell Lifting as a Means of Physical Training Cadets in Higher Military Educational Institution. Journal of Physical Education and Sport. 2017. 17 (4). P. 2685-2689.

23. Prontenko K., Griban G., Prontenko V., Bezpaliy S., Bondarenko V., Andreychuk V., Tkachenko P. Correlation Analysis of Indicators of Athletes' Readiness and their Competitive Results in Kettlebell Sport. Journal of Physical Education and Sport. 2017. 17 (Supplement issue 4). P. 2123-2128.

24.Prontenko K., Griban G., Prontenko V., Bezpaliy S., Bykova G., Zeleniuk O., Dvoretsky V. Level and Dynamics of Functional Preparedness Indexes of Kettlebell Sportsmen. Journal of Physical Education and Sport. 2017. 17 (2) P. 712-716.

25. Prontenko K., Griban G., Prontenko V., Opanasiuk F., Tkachenko P., Zhukovskyi Ye., Kostyuk Yu. Health Improvement of Cadets from Higher Military Educational Institutions During Kettlebell Lifting Activities. Journal of Physical Education and Sport. 2018. 18 (1). P. 298-303.

26. Prontenko K., Kuvaldina O., Martin V., Griban G., Prontenko V., Andreychuk V. Changes in the Body Mass Index of Cadets at the Higher Military Educational Institution as a Result of Kettlebell Lifting. Journal of Physical Education and Sport. 2017. 17 (4). P. 2674-2677.

\section{Information about the authors:} Griban Grygoriy Petrovych, Doctor of Pedagogical Sciences, Professor at the Department of Physical Education Polissia National University 7, Staryi boulevard, Zhytomyr, 10008, Ukraine

Tkachenko Pavlo Petrovych, Candidate of Pedagogical Sciences, Associate Professor, Head of the Department of Physical Education

Polissia National University 7, Staryi boulevard, Zhytomyr, 10008, Ukraine 